\title{
Penetapan Harga Dan Penguasaan Pasar Oleh Transportasi Online Dalam Perspektif Hukum Persaingan Usaha
}

\section{Aprilia Stefany Leliak¹, Gusti Ferdiany Sriwardan², Savina Ayu Maharani ${ }^{3}$}

1, 2, 3, Fakultas Hukum Universitas Airlangga, Surabaya, Indonesia

E-mail: apriliastefany5@gmail.com

\begin{tabular}{|c|c|}
\hline Dikirim: 19/09/2021 & Dipublikasi: $30 / 11 / 2021$ \\
\hline Info Artikel & Abstract \\
\hline \multirow[t]{2}{*}{$\begin{array}{l}\text { Keywords: } \\
\text { Pricing and Market Control; } \\
\text { Online Transportation; } \\
\text { Business Competition Law. }\end{array}$} & $\begin{array}{l}\text { Starting in 2014, the online transportation appeared, the vehicles used } \\
\text { by this transportation are also different from other conventional } \\
\text { transportation. People who are accustomed to using conventional } \\
\text { transportation can switch their interests due to cheaper fares and a more } \\
\text { practical ordering system, namely through online applications. The } \\
\text { chaos of online transportation stems from accusations that its presence } \\
\text { is considered illegal because it does not meet the implementation of } \\
\text { public transportation. The most basic thing is that initially online } \\
\text { transportation did not have an Indonesian legal entity, did not have a } \\
\text { public transportation business, and there was no obligation to conduct } \\
\text { a due diligence (KIR). As a result, online transportation does not pay } \\
\text { taxes, so online taxis are able to offer cheaper fares. Thus, it is necessary } \\
\text { to study further regarding the rules regarding the determination of } \\
\text { online transportation fares in Indonesia. Then there is a further study } \\
\text { regarding indications of unfair business competition with online } \\
\text { transportation fares. As a result, online transportation does not pay } \\
\text { taxes, so online taxis are able to offer cheaper fares. }\end{array}$ \\
\hline & Abstrak \\
\hline $\begin{array}{l}\text { Kata Kunci: } \\
\text { Penetapan Harga dan } \\
\text { Penguasaan Pasar; } \\
\text { Transportasi Online; } \\
\text { Hukum Persaingan Usaha. }\end{array}$ & $\begin{array}{l}\text { Mulai tahun } 2014 \text { munculah transportasi online tersebut, } \\
\text { kendaraan yang digunakan oleh transportasi ini pun berbeda } \\
\text { dengan transportasi konvensional lainnya. Masyarakat yang } \\
\text { terbiasa menggunakan transportasi konvensional dapat beralih } \\
\text { minatnya dikarenakan tarifnya yang lebih murah dan system } \\
\text { pemesanan yang lebih praktis yaitu melalui aplikasi online. } \\
\text { Kisruh transportasi online berpangkal pada tudingan bahwa } \\
\text { kehadirannya dianggap illegal karena tidak memenuhi } \\
\text { penyelenggaraan transportasi umum. Hal yang paling mendasar } \\
\text { adalah pada awalnya transportasi online tidak memiliki badan } \\
\text { hukum Indonesia, tidak memiliki usaha angkutan umum, serta } \\
\text { tidak adanya kewajiban melakukan uji kelayakan (KIR). } \\
\text { Dampaknya tranportasi online tidak membayar pajak, sehingga } \\
\text { taksi online mampu menawarkan tarif yang lebih murah. } \\
\text { Dengan demikian, Sehingga perlu dikaji lebih lanjut mengenai } \\
\text { aturan tentang penetapan tarif transportasi online di Indonesia. } \\
\text { Kemudian adanya pengkajian lebih lanjut mengenai adanya } \\
\text { indikasi persaingan usaha tidak sehat dengan tarif transportasi } \\
\text { online. Dampaknya tranportasi online tidak membayar pajak, }\end{array}$ \\
\hline
\end{tabular}


DOI:

10.47268/ballrev.v2i2.738 sehingga taksi online mampu menawarkan tarif yang lebih murah.

\section{Pendahuluan}

Ekonomi dunia dewasa ini bergerak sangat dinamis, dengan globalisasi sebagai motor penggeraknya. Globalisasi telah menjadi pendorong utama bagi munculnya integrasi ekonomi dunia. Melalui globalisasi dapat dilakukan peningkatan investasi, baik langsung maupun tidak langsung yang akhirnya mendorong pertumbuhan ekonomi dan lapangan kerja. Memerhatikan persaingan antar pelaku usaha yang bertambah ketat dan tidak sempurna (imperfect competition), maka nilai-nilai persaingan usaha yang sehat perlu mendapat perhatian lebih besar dalam system ekonomi Indonesia.

Penegakan hukum persaingan merupakan instrument ekonomi yang sering digunakan untuk memastikan bahwa persaingan antar pelaku usaha berlangsung dengan sehat dan hasilnya dapat terukur berupa peningkatan kesejahteraan masyarakat dengan mempertimbangkan amanat sesuai pasal 33 Undang-Undang Dasar Negara Republik Indonesia Tahun 1945 yang merumuskan Perekonomian disusun sebagai usaha bersama berdasar atas asas kekeluargaan" bahkan dalam Pasal 33 ayatnya ke 4 juga mengamanatkan "Perekonomian nasional diselenggarakan berdasar atas demokrasi ekonomi dengan prinsip kebersamaan, efisiensi berkeadilan, berkelanjutan, berwawasan lingkungan, kemandirian, serta dengan menjaga keseimbangan kemajuan dan kesatuan ekonomi nasional".

Indonesia adalah negara kepulauan tersebsar di dunia yang terdiri dari 17.504 pulau dan termsauk dalam negara berpenduduk terbesar keempat di duunia dengan jumlah lebih dari 230 (dua ratus tiga puluh) juta jiwa (Badan perencanaan Pembangunan Nasional dan Badan Pusat Statistik, 2013: 23), dalam hal ini untuk mendukung aktivitas yang dilakukan oleh penduduk Indonesia setiap harinya, transportasi tentunya sangat mendukung perpindahan masyarakat dari satu tempat ke tempat yang lain.

Sarana transportasi semakin berkembang seiring dengan berkembangnya teknologi zaman. Di Indonesia terdapat berbagai macam jenis transportasi yang dapat digunakan oleh masyarakat sebagai angkutan umum. Jika dahulu angkutan umum hanya berupa becak dan bemo, seiring perkembangan zaman transportasi telha mengalami perubahan yang semakin modern dalam hal ini sarana transportasi juga berubah da bertambah diantaranya kereta api, bus, taksi dan lain-lain. Namun padatnya jumlah penduduk angkutan umum menjadi tidak nyaman untuk digunakan karena harus berdesak-desakan dengan penumpang lainnya dalam angkutan umum tersebt. Sedangkann masyarakat juga menginginkan rasa nyaman pada saat menggunakan angkutan umum, meskipun harus mengeluarkan uang atau biaya lebih banyak.

Transportasi wilayah perkotaan merupakan sector penunjang utama terhadap mobilitas masyarakat perkotaan. Masyarakat memerlukan jasa transportasi untuk 
berkativitas. Jasa transportasi perkotaan yang efektif dan efisien mempunyai karakteristik sebagai berikut, yaitu (Adisasmita \& Adisasmita, 2011: 26-41):

a) Lancar atau cepat (Speed)

Cepat dalam transportasi dapat ditinjau dalam du acara. Pertama, waktu yang digunakan oleh kendaraan atau muatan (barang atau penumpang) selama perjalanan dari suatu tempat ke tempat yang lain. Kedua, waktu yang diperlukan untuk mempersiapkan barang-barang atau penumpang dari suatu perjalanan yang kemudian dilanjutkan dengan perjalanan berikutnya, termasuk waktu selang untuk pemuatan, pembongkaran, pengisian bahan bakar dan perbaikan kendaraan (Adisasmita, 2015: 36)

\section{b) Selamt atau Aman (Safety)}

Penyediaan alat-alat keselamatan lalu lintas yang cukup (meliputi rambu-rambu lalu lintas) merupakan usaha untuk mengurangi terjadinya kecelakaan lalu lintas yang merugikan manusia sebagi penumpang dan juga barang serta benda lainnya. Untuk angkutan penumpang, perlengkapan, dan alat keselamatan harus disediakan dan diberikan sanksi tegas terhadap pemilik sarana angkutaan apabila tidak menyediakan (Adisasmita, 2015: 37).

c) Berkapasitas (Capacity)

Fasilitas transportasi harus tersedia dalam jumlah yang cukup pada waktu yang diperlukan. Untuk angkutan penumpang jumlah kapasitas angkut harus dikaitkan pula dengan permintaan maksimum pada suatu titik waktu. Setiap hari di kota-kots pada jam-jam tertentu terjadi puncak kepadatan lalu lintas yang harus ditanggulangi (Adisasmita, 2015: 39) seperti halnya pada jam-jam berangkat dan pulang kerja.

d) Dilaksanakan dalam frekuensi yang memadai (Frequency)

Jasa transportasi dilaksanakan secara teratur atau secara tidak teratur, dan intervalnya (waktu selang) antara angkutan yang satu dengan angkutan berikutnya mungkin pendek dan mungkin pada panjang. Untuk angkutan penumpang, jasa transportasi yang dilakukan sering dan berjadwal berarti dapat kemungkinan dilakukannya perjalanan yang lebih luas dalam waktu yang terbatas (Adisasmita, 2015: 39).

e) Keteraturan (Regularity)

Keteraturan dalam jasa transportasi berarti bahwa fasilitas transportasi tersedia pada waktu-waktu yang telah ditentukan, sheingga memungkinkan masyarakat mengatur kegiatan-kegiatan dan perjalanan pribadinya. Masyarakat menginginkan pula perjalanan kea tau dari tempat pekerjaan atau kemana saja, mereka dapat memilih tranportasi yang diinginkan, sehingga mereka tiba di tempat tujuan pada suatu waktu yang telah direncanakan (Adisasmita, 2015: 40).

f) Komprehensif (Comprehensive)

Dalam pengertian ini jasa transportasi yang komprehensif harus dilihat dari segi luasnya, suatu usaha transportasi dapat melaksanakan tanggungjawab melayani 
pengangkutan yang sempurna meskipun pelayanannya menggunakan lebih dari satu sarana tranportasi (transportasi secara komprehensif), yang penting diperhatikan oleh para pengguna jasa transportasi yaitu pemilihan rute dan sarana transportasi yang dapat melayani perjalanan masyarakat yang paling sedikit mengalami pergantian dan juga pemindahan baik rute maupun saranana.

g) Bertanggung jawab (Responsibility)

Para pengguna jasa transportasi mengharapkan pengangkutan yang aman atau diberikan kompensasi atas kerugian, baim terhadap kehilangan ataupun kerusakan dan kecelakaan yang diakibatkan dari pengguna jasa transportasi tersebut. Bertanggung jwab dalam hal ini adalah merupakan suatu kulaitas yang diinginkan dalam pelayanan jasa transportasi, dalam bentu membayar klaim yang diajukan atas kerugian yang dialami.

h) Biaya Murah (Acceptable Cost) dan Harga Terjangkau (Affordable Price)

Biaya transportasi harus berhasil dalam menyelenggarakan lalu lintas. Penurunan biaya riil dicerminkan dalam permintaan yang bertambah besar. Penurunan biaya produksi akan memengaruhi lebih lanjut terhadap perluasan kegiatan-kegiatan ekonommi dan pembangunan. Biaya yang murah (rendah) diterjemahkan sebagai acceptable cost, tetapi dilihat dari harga yang terjangkau bagi masyarakat disebut affordable price.

i) Kenyamanan (Comfort)

Kenyamanan secara fisik meliputi penyediaan tempat duduk yang serasu, ventilasi, pengaturan suhu, dan kesegaran hawa dalam ruangan, kenyamanan dalam perjalanan harus diusahakan untuk meniadakan keadaan yang serba kurang menarik.

Namun dari beberapa macam sarana transportasi yang ada di Indonesia, ada sarana transportasi yang memberikan kenyamanan untuk digunakan oleh masyarakat. Alat transportasi tersebut adalah Transportasi online seperti Gojek, Gocar, Grab dan lain sebagainya. Ada berbagai alasan Transportasi online masih dirasa memberikan kenyamanan kepada masyarakat selain mudah untuk diakses, layanannya yang privat dan ekslusif, menjemput dan mengantar penumpang langsung ke tempat tujuan serta tidak adanya batasan-batasan rute tertentu, bahkan dengan harga yang tergolong terjangkau disesuaikan dengan lokasi yang dituju dengan adanya kode promo tertentu. Menjadikan Transportasi online sebagai transportasi yang efisien dan efektif guna mendukung aktivitas masyarakat yang memiliki mobilitas tinggi.

Mulai tahun 2014 munculah transportasi online tersebut, kendaraan yang digunakan oleh transportasi ini pun berbeda dengan transportasi konvensional lainnya. Masyarakat yang terbiasa menggunakan transportasi konvensional dapat beralih minatnya dikarenakan tarifnya yang lebih mura dan system pemesanan yang lebih praktis yaitu melalui aplikasi online. Transportasi online ini juga memiliki keunggulan-keunggulan lain selain tarifnya lebih murah para penumpang tidak perlu menunggu kendaraan di pinggir jalan, cukup memesan melalui aplikasi 
telepon genggam, para calon penumpang transportasi online juga dapat mengetahui harga jasa transportasi yang harus dibayarkan dari aplikasi, tanpa perlu menebaknebak, atau memikirkan tarifnya akan berkahir dengan biaya mahal atau tidak, dan yang terakhir pasa sisi teknologi transportasi online lebih canggih daripada transportasi Konvensional.

Kisruh transportasi online berpangkal pada tudingan bahwa kehadirannya dianggap illegal karena tidak memenuhi penyelenggaraan transportasi umum. Hal yang paling mendasar adalah pada awalnya transportasi online tidak memiliki badan hukum Indonesia, tidak memiliki usaha angkutan umum, serta tidak adanya kewajiban melakukan uji kelayakan (KIR). Dampaknya tranportasi online tidak membayar pajak, sehingga taksi online mampu menawarkan tarif yang lebih murah. Hal tersebut membuat penetrasi tranportasi online dalam tempo singkat mampu menggerus pasar transportasi konvensional (Safitri, 2015).

Kondisi inilah yang menyulut penolakan keras dari perusahaan angkutan umum konvensional. Namun, pemerintah tidak merespon pergeseran model bisnis angkutan umum, melainkan hanya meminta perusahaan transportasi online membentuk badan hukum Indonesia. Tetapi hal tersebut belum menyelesaikan masalah, dikarenakan yang menjadi inti permasalahan adalah perbedaan tarif yang sangat signifikan (Safitri, 2015), tepat pada 1 April 2017 pemerintah melalui kementrian perhubungan telah menetapkan peraturan Menteri Perhubungan (Permenhub) Nomor 26 Tahun 2017 tentang Penyelenggaraan Angkutan Orang dengan Kendaraan Bermotor Umum Tidak Dalam Trayek (selanjutnya disebut dengan Pemenhub Nomor 26 Tahun 2017) guna mengatur keberadaan transportasi transportasi berbasis online. Namun Keberlakuan Permenhub tersebut tidak lama karena sudah dicabut oleh Mahkamah Agung. Mahkamah Agung menyatakan aturan tersebut bertentangan dengan UU Usaha Mikro, kecil, menengah serta UU Lalu Lintas dan Angkutan Jalan. Dalam hal ini dalam pertimbangan majelis hakim bahwa penyusunan regulasi dibidang transportasi berbasis teknologi dan informasi seharusnya didasarkan pada musyawarah mufakat yang melibatkan seluruh stakeholder dibidang jasa transportasi, sehingga secara bersama dapat menumbuhkembangkan usaha ekonomi mikro, kecil, menengah, tanpa meninggalkan asas kekeluargaan. Sehingga terbit aturan yang dikeluarkan olehh Menteri Perhubungan yaitu Permenhub Nomor PM 108 Tahun 2017 tentang penyelenggaran Angkutan Orang dengan Kendaraan Bermotor Umum Tidak dalam Trayek bahkan hingga saat ini dirubah beberapa pasal didalamnya dengan Permenhub Nomor PM 15 Tahun 2019 tentang Penyelenggaraan Angkutan Orang dengan Kendaraan Bermotor Umum Tidak dalam Trayek. Sehingga perlu dikaji lebih lanjut mengenai aturan tentang penetapan tarif transportasi online di Indonesia. Kemudian adanya pengkajian lebih lanjut mengenai adanya indikasi persaingan usaha tidak sehat dengan tarif transportasi online.

\section{Metode Penelitian}

Penelitian ini menggunakan jenis penelitian "Normatif", yaitu penelitian tertutama mengkaji bahan-bahan hukum, ketentuan-ketentuan dalam aturan aturan 
atau hukum positif, asas-asas hukum atau prinsip-prinsip hukum maupun doktrin hukum, guna menjawab isu hukum "Penetapan Harga dan Penguasaan Pasar Oleh Transportasi Online Dalam Perspektif Hukum Persaingan Usaha”. Guna melengkapi jenis penelitian untuk memberi arah dalam penulisan ini maka tipe penelitian bersifat "Deskripstif analstis", maksudnya bahwa hukum yang ditemukan selanjutnya dianalisis dan dibahas dengan berpatokan ahli sehingga hasilnya dapat dideskripsikan untuk membantu penarikan kesimpulan dan saran. Di dalam penelitian hukum terdapat beberapa pendekatan dan dengan pendekatan tersebut memungkinkan peneliti mendapat informasi dari berbabgai aspek mengenai permasalahan yang sedang diteliti dan dicari jawabannya. Menurut Petter Mahmud Marzuki, pendekatan-pendekatan yang digunakan dalam suatu penelitian hukum adalah: Pendekatan Undang-Undang (Statute Approach), Pendekatan Kasus (Case Approach), Pendekatan Histori (Historical Approach), Pendekatan Komparatif (Comperatife Approach), dan Pendekatan Konseptual (Conseptual Approach) (Marzuki, 2016: 35). Pendekatan-Pendekatan yang digunakan dalam penelitian ini: a).Pendekatan Perundag-undangan, melalui pendekatan undang-undang akan dicari aturan-aturan hukum yang berkaitan secara langsung sehingga menjadi landasan hukum mengenai Penetapan Harga Dan Penguasaan Pasar Oleh Transportasi Online Dalam Perspektif Hukum Persaingan Usaha. b).Pendekatan Konseptual. Pendekatan ini digunakan untuk melakukan pengkajian dan menganalisis khusus terkait dengan "Trasnportasi Online" karena inti dari penelitian ini adalah Penetapan Harga Dan Penguasaan Pasar Oleh Transportasi Online Dalam Perspektif Hukum Persaingan Usaha. Sehingga perlu ditelaah prinsip-prinsip atau asas-asas hukum, doktrin hukum yang membahas konsep tersebut. c).Pendekatan Kasus (Case Approach). Pendekatan ini digunakan di dalam penelitian ini adalah untuk mengkaji kasus yang bisa membuktikan Indikasi Persaingan Usaha Tidak Sehat terhadap tarif Transportasi Online dan implikasi atas Undang-Undang Nomor 5 Tahun 1999 tentang Larangan Praktek Monopoli dan Persaingan Usaha di Indonesia seiring dengan perkembangan Ilmu Pengetahuan dan Teknologi.

\section{Hasil dan Pembahasan}

\subsection{Pengaturan Tentang Penetapan Tarif Transportasi Online Di Indonesia}

Transportasi Motor dan Mobil merupakan alat transportasi umum yang semakin banyak dan berkembang di Indonesia. Angkutan orang dengan kendaraan bermotor umum berdasarkan Pasal 140 Undang-Undang Nomor 22 Tahun 2009 tentang Lalu Lintas dan Angkutan Jalan dibedakan menjadi dua yaitu:

a) Angkutan orang dengan Kendaraan Bermotor Umum dalam trayek; dan

b) Angkutan orang dengan Kendaraan Bermotor Umum tidak dalam trayek.

Berdasarkan Undang-Undang Lalu Lintas dan Angkutan Jalan, yang dimaksud dengan trayek dalam penjelasan Pasal 140 Undang-Undang Nomor 22 Tahun 2009 tentang Lalu Lintas dan Angkutan Jalan adalah lintasan kendaraan bermotor umum untuk pelayanan jasa angkutan, yang mempunyai asal dan tujuan perjalanan tetap, serta lintasan tetap, baik berjadwal maupun tidak berjawal. Sehingga dapat 
disimpulkan bahwa angkutan umum transportasi online adalah angkutan orang dengan kendaraan bermotor umum tidak dalam trayek dikarenakan angkutan umum taksi tidak mempunyai lintasan yang tetap dan juga asal dan tujuan perjelanan yang tidak tetap. Kategori transportasi online dimasukan dalam angkutan orang dengan kendaraan bermotor umum tidak dalam trayek juga dapat kita lihat pada Undang-Undang Nomor 22 Tahun Tentang Lalu Lintas dab Angkutan Jalan (Selanjutnya disebut dengan UU Nomor 22 Tahun 2009) "Pelayanan Angkutan Orang dengan Kendaraan Bermotor Umum tidak dalam trayek sebagaimana dimaksud dalam Pasal 140 huruf b terdiri dari;

a) Angkutan orang dengan menggunakan taksi

b) Angkutan orang dengan tujuan tertentu

c) Angkutan orang untuk keperluan pariwisata, dan

d) Angkutan orang di Kawasan tertentu.

Seiring dengan berkembangnya zaman pada tahun 2014 lalu terjadi sebuah revolusi kreatif dibidang layanan transportasi, pelayanan jasa transportasi berbasis aplikasi online. Pelayanan jasa trasportasi berbasis aplikasi online ini dibagi menjadi dua tipe pelayanan kendaraan dan ada yang menggunakan mobil sebagai pesaing dari taksi.

Keberadaan Transportasi online diatur dengan adanya Peraturan Mentri Perhubungan Nomor PM 117 Tahun 2018 tentang Penyelenggaraan Angkutan Orang Dengan Kendaraan Bermotor Umum tidak Dalam Trayek (selanjutnya disebut dengan Permenhub Nomor 117 Tahun 2018), keberadaan taksi online dikategorikan ke dalam angkutan sewa khusus, yang diatur dalam pasal 26 ayat (1) yang merumuskan: "Angkutan Sewa Khusus sebagaimana dimaksud dalam Pasal 13 huruf $g$ merupakan pelayanan angkutan dari pintu ke pintu dengan pengemudi, memiliki wilayah operasi dalam perkotaan dari dan ke bandar udara, pelabuhan, atau simpul transportasi lainnya serta pemesanan, menggunakan aplikasi berbasis teknologi informasi, dengan besaran tarif tercantum dalam aplikasi."

Pangsa Pasar adalah penguasaan suatu produk atau besarnya jumal produk yang diminta yang dihasilkan oleh suatu perusahaan dibandingkan dengan jumlah permintaan yang terjadi di suatu pasar. Dapat juga dikatakan bahwa pangsa pasar adalah besarnya bagian pasar yang dikuasai oleh suatu perusahaan. Besarnya pangsa pasar dapat berubah sesuai dengan terjadinya perubahan pada selera masyarakat sebagai konsumen dari suatu produk ke produk lain.

Konsentrasi pasar merupakan indikator awal untuk menilai apakah Penggabungan Badan Usaha, Peleburan Badan Usaha, atau Pengambilalihan saham perusahaan dapat mengakibatkan terjadinya Praktik Monopoli dan/atau Persaingan Usaha Tidak Sehat. Penggabungan Badan Usaha, Peleburan Badan Usaha, atau Pengambilalihan saham perusahaan yang menciptakan konsentrasi pasar rendah tidak berpotensi mengakibatkan Praktik Monopoli dan/atau Persaingan Usaha Tidak Sehat. Sebaliknya Penggabungan Badan Usaha, Peleburan Badan Usaha, atau Pengambilalihan saham perusahaan yang menciptakan konsentrasi pasar tinggi berpotensi mengakibatkan Praktik Monopoli dan/atau Persaingan Usaha Tidak 
Sehat bergantung pada analisis lainnya pada pasar bersangkutan. Konsentrasi pasar biasanya diukur dengan menggunakan Concentration Ratio dan Herfindahl Index (Stephen, 1989: 55).

Hasil dari pengukuran konsentrasi pasar dapat digunakan sebagai indikator struktur suatu pasar. Enam bentuk struktur pasar, yaitu monopoli (1 perusahaan menguasai $100 \%$ pangsa pasar), dominan perusahaan (1 perusahaan menguasai $40 \%$ sampai dengan 99\% pangsa pasar), oligopoli kuat (4 perusahaan menguasai lebih dari $60 \%$ pangsa pasar), oligopoli lemah (4 perusahaan menguasai kurang dari $40 \%$ pangsa pasar), persaingan monopolistik (banyak perusahaan dan masing-masing perusahaan memiliki kekuatan yang kecil), dan persaingan sempurna (banyak perusahaan, dan setiap perusahaan tidak memiliki kekuatan pasar) (Beattie et al., 2003).

Pangsa pasar Transportasi memerlukan kajian secara industry yaitu melalui langkah pertama yang harus dilakukan adalah menentukan pasar bersangkutan (relevant market). Menentukan pasar bersangkutan harus secara tepat guna mengukur struktur pasar dan batasan dari perilaku anti persaingan yang dilakukan, dengan diketahuinya pasar bersangkutan maka setelah itu dapat diidentifikasi pesaing nyata dari pelaku usaha dominan yang dapat membatasi perilakunya (Lubis et al., 2009: 50). Menurut Undang-Undang Nomor 5 Tahun 1999 tentang Larangan Praktek Monopoli dan Persaingan Usaha Tidak Sehat (selanjutnya disebut UU Nomor 5 Tahun 1999) pasar bersangkutan didefinisikan sebagai berikut: "Pasar bersangkutan adalah pasar yang berkaitan dengan jangkauan atau daerah pemasaran tertentu oleh pelaku usaha atas barang dana tau jasa yang sama atau sejenis atau substitusi dari barang dana tau jasa tersebut".

Dilihat dari definisinya, dapat diketahui bahwa terdapat dua batasan dimensi dalam pasar bersangkutan, yaitu dimensi produk (set of products) dari kalimat: ..." atas barang dana tau jasa yang sama atau sejenis atau substitusi dari barang dana tau jasa tersebut", dan juga dimensi wilayah (relevant geographic market) dari kalimat: “...berkaitan dengan jangkauan atau daerah pemasaran tertentu...(Lubis et al., 2009)"

1) Pasar Berdesarkan Produk

Pasar produk didefinisikan sebagai produk-produk pesaing dari produk tertentu, ditambah dengan produk lain yang bisa menjadi substitusi dari produk tersebut atau dengan kata lain pasar berdasarkan produk terkait dengan kesamaan, atau kesejenisan dan/atau tingkat substitusinya (Nugroho, 2012). Dari pengertian pasar bersangkutan dapat digantikan dengan produk lain dapat dinyatakan sama atau dapat dinyatakan sama atau dapat dinyatakan menjadi subtitusi terhadap barang tertentu, perlu ddilihat dari 4 aspek yaitu a) bentuk lahirlah dan sifat barang tersebut, b) fungsi barang tersebut; c) harga barang tersebut; dan d)fleksibelitas barang tersebut bagi konsumen (Lubis et al., 2009: 176).

2) Pasar Berdasarkan Geografis 
Penetapan pasar bersangkutan berdasarkan aspek geograsi atau daerah/teritori yang merupakan lokasi pelaku usaha melakukan kegiatan usahanya, dan/ atau lokasi ketersediaan atau peredaran produk dan jasa dan/ atau dalam hal ini beberapa daerah memiliki kondisi persaingan relative seragam dan berbeda disbanding kondisi persaingan di daerah lainnya atau dapat dikatakan pasar berdasarkan cakupan geografis terkait dengan jangkauan dan/atau daerah pemasaran (Nugroho, 2012: 386).

Hadirnya Uber, Grab dan Gojek mengubah keadaan persaingan di bidang jasa layanan transportasi. Hadirnya Transportasi online mengurangi pangsa pasar transportasi konvensional. Persaingan antara transportasi Konvensional dan transportasi online tak dapat dihindari. Terbentuknya hubungan antara inovasi dan kebijakan persaingan harus dipamahami bersama bahwa proses inovasi harus dilindungi dengan membiarkan pasar terbuka bagi para inovator potensioal. Maka dari itu menentukan pasar bersangkutan sangat penting untuk menentukan apakah tindakan yang diambil oleh pelaku usaha di pasr bersifat antikompetitif atau tidak.

Dilihat dari sisi pasar permintaan secara sederhana transportasi online dengan transportasi konvensional berada pada pasar bersangkutan yang sama tetapi sisi pasar penawaran perlu dikaji lebih dalam lagi karena inovasi yang dilahirkan oleh transportasi online justru pada system aplikasi yang diciptakan guna mempermudah calon penumpang untuk memesan (Nugroho, 2012: 386). Berdasarkan analisis diatas dapat disimpulkan bahwa transportasi konvensional dan transportasi online berada dalam pasar bersangkutan yang sama, dengan hadirnya pesaing baru dalam pasar yang sama, maka transportasi konvensional harus melakukan inovasi.

Kebijakan penentuan tarif oleh pemerintah dianggap sebagai kebijakan multisisi, maksud dari kebijakan multisasi adalah di suatu sisi dapat dipandang sebagai alat pengendali lalu lintas, di sisi lain dapat berarti sebagai alat untuk mendorong masyarakat menggunakan kendaran umum dan mengurangi penggunaan kendaraan pribadi.

Kebijakan tariff yang berlaku di Indonesia, menurut Suwardjoko P. Warpani mengacu pada pendekatan sebagai berikut (Warpani, 2002: 150-152):

1) Pendekatan Penyedia Jasa

Apabila kebijakan tariff yang berdasarkan pendekatan penyedia jasa dimaksudkan untuk menjada kelangsungan hidup dan pengembangan usaha jasa pengangkutan, serta demi menjaga kelancaran penyediaan jasa, keamanan, kenyamanan layanan jasa pengangkutan, maka:

a) Tarif didasarkan atas berbagai biaya yang dikeluarkan, dalam arti dapat menutup seluruh biaya produksi jasa pengangkutan dan memperoleh kelnihan berupa laba;

b) Tarid seharusnyaa dapat memberikan pendapatan yang layak bagi penyedia jasa, sehingga upaya pemeliharaan sarana dan prasarana dapat terpenuhi dan pengembalian investasi dapat diwujudkan dalam relative tidak lama; 
c) Untuk investasi yang besar dengan tingkat pengembalian modal yang cukup lama, maka tariff diharapkan (dalam jangka panjang) lebih tinggi dari biaya marjinal;

d) Tarif diharapkan dapat menimbulkan alokasi modal yang rasional bagi pembangunan dan pengembangan usaha pengangkutan serta mendorong tercapainya pemerataan pembangunan;

e) Jika penyusunan struktur penyediaan jasa yang efisien dapat dikembangkan ke arah produktivitas setiap jenis jasa yang diperlukan, maka jasa pengangkutan dapat dikelompokan pada setiap pelayanan, sehingga pengklasifikasian tarif yang sesuai dengan jasa tersebut dapat disusun.

2) Pendekatan Pengguna Jasa

Jika pendekatan berdasarkan pengguna jasa dimaksud agar tarif tidak terlalu memberatkan pengguna jasa dan memperlancar mobilitas baik penumpang maupun barang, maka;

a) Tarif harus rasional, diberlakukan secara umum, layak dan adil serta tidak diskriminatif dalam pengklasifikasiannya;

b) Tarif diharapkan dapat merangsang peningkatan kegiatan dunia usaha dan mendorong pertumbuhan produksi secara menyeluruh

c) Tarif diharapkan dapat terjangkau oleh daya beli pengguna jasa

d) Tarif diharapkan dapat membantu perkembangan integritas social masyarakat khususnya bagi angkutan penumpang

e) Tarif harus dapat mendorong dan mengembangkan distribusi pemsaran yang luas

f) Tariff sebagai unsur biaya pada kalkulasi harga pokok barang diharapkan dapat ditekan sekecil mungkin

3) Pendekatan Pemerintah

Pendekatann pemerintah yang dimaksud untuk mendorong pembangunan ekonomi serta menjaga stabilitas politik dan keamanan dalam rangka globalisasi, meliputi;

a) Mengendalikan tarif yang dapat menjamin dan mendorong penggunaan secara maksimal

b) Menjaga keseimbangan antara kepentingan pengguna jasa dengan penyedia jasa

c) Mengembangkan dan mendorong saran dengan memerhatikan perkembangan teknologi

d) Mencapai keadaan alokasi sumber daya yang optimum dengan memerhatikan kriteria efisiensi dan pemerataan pembangunan

e) Menunjang upaya tercapainya kesejahteraan social bagi masyarakat

f) Memerhatikan dan melaksanakan hal-hal yang berkaitan dengan pertumbuhan, penyebaran dan struktur kependidikan

g) Menjaga tingkat pelayanan (level service) dalam rangka peningkatan kinerja layanan jasa pengangkutan. 
Dalam menentukan tariff jasa angkutan, beberapa hal yang patut menjadi dasar pertimbangan adalah (Warpani, 2002: 153):

1) Kelangsungan hidup dan pengembangan usaha jasa angkutan;

2) Daya beli masyarakat pada umumnya;

3) Tingkat Bunga modal;

4) Jangka waktu pengembalian modal;

5) Biaya social (Social Cost) yang ditimbulkan karena operasional jasa angkutan.

Teori biaya sosial dalam hal ini menegaskan bahwa pelaku usaha wajib menanggung dan memerhatikan semua kerugian termasuk kerugian yang tidak dapat diperhitungkan sebelumnya yang diakibatkan oleh operasional perusahaan. Perihal mengenai tarif transportasi Konvensional diatur dalam Pasal 183 ayat 1 dan Pasal 185 UU Nomor 22 Tahun 2009, dalam hal ini menjelaskan tarif penumpang untuk angkutan orang tidak dalam trayek menggunakan taksi ditetapkan oleh perusahaan dan Tarif penumpang umum angkutan tidak dalam trayek dengan tujuan tertentu, pariwisata dan di kawasan tertentu ditetapkan berdasarkan kesepakatan antar pengguna jasa dan perusahaan Angkutan Umum. Angkutan Penumpang Umum dengan tarif kelas ekonomi pada trayek tertentu dapat diberi subsidi oleh Pemerintah dan/atau Pemerintah Daerah.

Perihal pengaturan tarif transportasi online, maka dapat dilihat dalam Permenhub Nomor 117 Tahun 2018, yang diatur dalam pasal 28 yang merumuskan; “Angkutan Sewa Khusus sebagaimana dimaksud dalam Pasal 13 huruf g merupakan pelayanan angkutan dari pintu ke pintu dengan pengemudi, memiliki wilayah operasi dalam perkotaan dari dan ke bandar udara, pelabuhan, atau simpul transportasi lainnya serta pemesanan, menggunakan aplikasi berbasis teknologi informasi, dengan besaran tarif tercantum dalam aplikasi.

\subsection{Indikasi Persaingan Usaha Tidak Sehat terhadap Tarif Transportasi Online dan Implikasi atas Undang-Undang Nomor 5 Tahun 1999 tentang Larangan Praktek Monopoli dan Persaingan Usaha di Indonesia seiring dengan perkembangan Ilmu Pengetahuan dan Teknologi}

Persaingan usaha tidak sehat adalah tindakan yang bersifat menghalangi atau mencegah persaingan. Tindakan seperti ini digunakan oleh pelaku usaha yang ingin memegang posisi monopoli degan mencegah calon pesaing atau menyingkirkan pesaing secara tidak wajar. Bagi sebagian pelaku usaha persaingan sering dianggap sebagai sesuatu hal yang negatif, kurang menguntungkan, karena dalam persaingan itu ada beberapa unsur yang perlu direbut dan dipertahankan seperti pangsa pasar, konsumen, harga dan sebagainya. Jika banyak pelaku usaha yang terlibat dalam proses persaingan maka keuntungan bagi pelaku usaha itu semakin berkurang (Makarao \& Suharsil, 2010: 52).

Hukum persaingan usaha bertujuan untuk memajukan persaingan dan inovasi (Akyuwen et al., 2021). Menjadi unggul di pasar bersangkutan merupakan salah satu tujuan pelaku usaha. Dalam industri apapun akan selalu ada satu pelaku usaha yang dominan dan beberapa pelaku usaha yang lebih kecil. Pelaku usaha dominan 
(dominant company) merupakan pelaku usaha dengan pangsa pasar yang besar yang dapat memengaruhi harga pasar dengan meningkatkan produksinya. Pelaku usaha seringkali berperan sebagai penentu harga (price setter) yaitu sebagai price taker sehingga memiliki kekuatan pasar yang besar (Nugroho, 2012: 389-390).

Lahirnya Undang-Undang Nomor 5 Tahun 1999 tentang Praktik Monopoli dan Persaingan Usaha Tidak Sehat berawal dari penandatanganan Letter of Intens (LOI) antara pemerintah Indonesia dengan International Monetary Fund (IMF) pada tanggal 29 Juli 1998 sebagai peristiwa penting terciptanya undang-undang Anti Monopoli di Indonesia (Hermansyah, 2008: 55).

Menurut rumusan Pasal 1 angka 6 Undang-Undang Nomor 5 Tahun 1999 tentang larangan Praktik Monopoli dan Persaingan Usaha Tidak Sehat, yang dimaksud dengan persaingan usaha tidak sehat adalah persaingan antar pelaku usaha dalam menjalankan kegiatan produksi dan/atau pemasaran barang dan/atau jasa yang dilakukan dengan cara tidak jujur atau melawan hukum atau menghambat persaingan usaha.

Perumusan di dalam Pasal 1 angka 6 Undang -Undang Nomor 5 Tahun 1999 tentang larangan Praktik Monopoli dan Persaingan Usaha Tidak Sehat memberikan suatu pengertian adanya pertentangan/persaingan diantara para pelaku usaha dengan cara yang tidak sehat dalam pelaksanaan kegiatan usaha. Menurut Sunaryati Hartono kompetisi merupakan 'bersaing' atau 'persaingan', yang mengutip dari Black's Law Dictionary, yaitu dari kata competition (Hartono, 1999: 7-8).

Kelemahan konsep pengertian persaingan usaha tidak sehat dalam UndangUndang No.5 Tahun 1999 tentang larangan Praktik Monopoli dan Persaingan Usaha Tidak Sehat bahwa pengertian tersebut tidak dirinci secara baik perbuatan apa saja yang termasuk dalam persaingan usaha tidak sehat tersebut, sehingga pengertian usaha tidak sehat selalu menjadi kata alternatif dalam setiap pasal selain monopoli sebagai salah satu akibat yang timbul dari perjanjian atau perbuatan yang dilarang, menjadi tidak jelad dan multiinterpretasi (Ginting, 2001: 21).

Suatu proses pasar hanya dapat dikembangkan di dalam struktur pengembalian keputusan yang terdesebtralisasi artinya bahwa terdapat individuindividu independen dalam jumlah secukupnya yang menyeddiakan pemasokann dan permintaan dalam suatu pasar karena proses pasar memerlukan saat aksi-aksi dan reaksi-reaksi pelaku pasar yang tidak dapat diprediksi. Ini adalah satu-satunya cara untuk menjamin bawha kekeliruan perencanaan oleh individu tidak semakin terakumulasi hingga akhirnya menghentikan fungsi pasar (Lubis et al., 2009: 2), dalam hal ini persaingan usaha akan terjadi apabila ada dua pelaku usaha atau lebih yang menawarkan barang dan jasa kepada konsumen dalam sebuah pasar.

Persaingan usaha pada umumnya terbagi menjadi dua yaitu, persaingan usaha sehat (Fair Competation) dan persaingan usaha tidak sehat (Unfair Competation) (Lubis et al., 2009: 30-31):

a) Persaingan Usaha Sehat 
Dalam hal ini untuk melindungi pelaku usaha baru naik yang sama jenisnya maupun berkaitan dengan jenis usaha lain yang merupakan pesaing. Dengan adanya Persaingan Usaha Sehat pelaku usaha dapat masuk ke pasar tanpa menghalangi pelaku usaha lain.

Dalam pasar persaingan sempurna, jumlah perusahaan sangat banyak dan kemampuan setiap perusahaan dianggap sedemikian kecilnya, sehingga tidak mampu memengaruhi pasar. Tetapi diperlukan beberapa karakteristik agar sebuah pasar dapat dikatakan pasar persaingan sempurna. Karakteristik pasar persaingan sempurna adalah:

1) Banyak Penjual dan Pembeli (Many Sellers and Buyers)

Jumlah Perusahaan yang sangat banyak mengandung asumsi implisit bahwa output sebuah perusahaan relative kecil disbanding output pasar (small relatively outpu). Semua perusahaan industry (pasar) dianggap berproduksi secara efisiensi (biaya rata-rata rendah) baik dalam jangka penndek maupun jangka panjang. Kendatipun demikian jumlah output setiap perusahaan secara individu dianggap realtif kecil disbanding jumlah output seluruh perusahaan dalam industry.

2) Produk Homogen (Homogen Product)

Produk yang homogeny adalah produk yang mampu memberikan kepuasan (utilitas) kepada konsumen tanpa perlu mengetahui siapa produsennya. Konsumen tidak membeli merk barang teteapi kegunaannya barang, karena itu semua perusahaan dianggap mampu memproduksi barang dan jasa dengan kualitas dan karakteristik yang sama.

3) Bebas Masuk dan Keluar Pasar (Free Entry and Free Exit)

Pemikiran yang mendasari asumsi ini adalah dalam pasar persaingan sempurna faktor produksi mobilitasnya tidak terbatas dan tidak ada biaya yang harus dikeluarka untuk memindahkan faktor produksi.

4) Informasi Sempurna (Perfect Knowledge)

Para pelaku ekonomi (konsumen dan produsen) memiliki pengetahuan sempurna tentang harga produk dan input yang dijual, dengan demikian konsumen tidak akan mengalami perlakuan harga jual yang berbeda dari satu perusahan dengan perusahaan lainnya.

Keempat Karakteristik tersebut menimbulkan suatu konsekuensi yaitu perusahaan di pasar tidak dapat menentukan harga sendiri. Penetapan harga yang kontras antara transportasi konvensional dan transportasi online menjadi titik permasalahan yang dapat dikaitkan dengan indikasi persaingan usaha tidak sehat antara transportasi konvensional dengan transportasi online. Dalam UU Nomor 5 Tahun 1999 penetapan harga diatur dalam Pasal 5,6,7, dan 8, yang dalam hal ini Pasal 5 diatur mengenai perjanjian penetapan harga (price fixing agreement), Pasal 6 mengatur mengenai perjanjian diskriminasi harga (price discrimination agreement), dan Pasal 7 mengatur mengenai perjanjian penetapan harga di bawah harga pasar atau jual rugi (predatory pricing). 
Perjanjian penetapan harga (price fixing agreement) menurut Pasal 5 ayat (1) UU Nomor 5 Tahun 1999 merumuskan: "Pelaku usaha dilarang membuat perjanjian dengan pelaku usaha pesaingnya untuk menetapkan harga atas suatu barang dan atau jasa yang harus dibayar oleh konsumen atau pelanggan pada pasar bersangkutan yang sama". Berdasarkan Pasal tersebut apabila dikaitkan dengan perkara antara Transportasi Konvensional dan Transportasi Online, bahwa tidak ada perjanjian diantara kedua belah pihak untuk menetapkan harga yang dapat menimbulkan minimnya persaingan dan meniadakan pilihan lainnya baik yang ditawarkan oleh penyedia jasa maupun yang akan dipilih konsumen menurut kebutuhannya. Tidak ada indikasi perjanjian penetapan harga antara pelaku usaha yang ditujukan untuk menciptakan hambatan masuk (barrier to entry) yang cukup besar, hal tersebut dapat menghambat pelaku usaha baru untuk masuk dalam pasar bersangkutan.

Perjanjian diskriminasi harga (price discrimination agreement) menurut Pasal 6 UU Nomor 5 Tahun 199 yang merumuskan "Pelaku usaha dilarang membuat perjanjian yang mengakibatkan pembeli yang satu harus membayar dengan harga yang berbeda dari harga yang harus dibayar oleh pembeli lain untuk barang dan atau jasa yang sama". Sehingga dapat disimpulkan dengan perkara Trasnportasi online dan Konvensional adalah terjadi diskriminasi harga antar pelaku usaha. Dalam hal ini, masing-masing pihak menjual jasa hanya terpusat pada kualitas pelayanan dengan menyesuaikan tarif masing-masing.

Perjanjian Penetapan harga dibawah harga pasar atau jual rugi (predatory pricing) menurut Pasal 7 UU Nomor 5 Tahun 1999 merumuskan "Pelaku usaha dilarang membuat perjanjian dengan pelaku usaha pesaingnya untuk menetapkan harga di bawah harga pasar, yang dapat mengakibatkan terjadinya persaingan usaha tidak sehat". Dapat dilihat bahwa trasnportasi online memasang tarif yang sangat rendah dan dalam waktu singkat dapat mengambil alih pasar transportasi konvensional.

Asas dari UU No. 5 Tahun 1999 sebagaimana diatur pada Pasal 2 bahwa "pelaku usaha di Indonesia dalam menjalankan kegiatan usahanya berasaskan demokrasi ekonomi dengan memperhatikan keseimbangan antar kepentingan pelaku usaha dan kepentingan umum". Asas demokrasi ekonomi tersebut merupakan penjabaran Pasal 33 UUD 1945 dan ruang lingkup pengertian demokrasi ekonomi yang dimaksud dahulu dapat ditemukan dalam penjelasan atas Pasal 33 UUD NRI Tahun 1945.

Adapun tujuan dari UU No. 5 Tahun 1999 sebagaimana diatur pada Pasal 3 adalah untuk: a. Menjaga kepentingan umum dan meningkatkan efisiensi ekonomi nasional sebagai salah satu upaya untuk meningkatkatkan kesejahteraan rakyat; b.Mewujudkan iklim usaha yang kondusif melalui pengaturan persaingan usaha yang sama bagi pelaku usaha besar, pelaku usaha menengah dan pelaku usaha kecil; c. Mencegah praktek monopoli dan/atau persaingan usaha tidak sehat yangvditimbulkan oleh pelaku usaha; d.Terciptanya efektivitas dan e. efisiensi dalam kegiatan usaha. 
Indonesia sedang dihadapkan dengan permasalahan economic security atau pertahanan ekonomi di sector pengemudi dan penyedia layanan transportasi. Pertahanan ekonomi adalah sebuah situasi dimana memiliki pendapatan financial yang stabil untuk memenuhi kebutuhan standar hidup saat ini dan di masa depan.

Hukum sebagai nilai-nilai yang menggambarkan abstraksi dari nurani manusia dan kemanusiaan mengenai adil dan tidak adil, benar dan tidak benar, sah dan tidak sah, patut dan tidak patut, pada hakikatnya mampu mengimbangi perkembangan ilmu pengetahuan dan teknologi. Secara rinci hukum akan menampakkan diri sebagai seperangkat peraturan yang didalamnya mengandung nilai mengenai, antara lain (Panglaykim, 1983: 18):

1) Pemanfaatan IPTEK secara maksimal yang tidak membahayakan kehidupan manusia

2) Tidak melanggar kepentingan dan hak pribadi maupun hak public masyarakat

3) Pengakuan dan prosedur pengakuan hak oleh negara di bidang hak kekayaan intelektual

4) Pengaturan tentang/mengenai keseimbangan kepentingan public terhadap kepentingan individu kelompok public, sebagai keseimbangan kepentingan para pihak.

Mengingat luasnya dan tipisnya batas antara nilai kemanfaatan dengan dampak yang timbul dari teknologi, maka sangat dibutuhkan berbagai aspek hukum sekaligus untuk mengatur penggunaan teknologi pada umumnya, ada beberapa macam bentuk intervensi yang dapat dilakukan untuk menyelesaikan masalah dalam dunia IPTEK ini, yaitu: 1. Business to business; 2. Government to business; 3. Personal to business (Nasution, 1993: 64). Kategori pertama dan kedua, business to business dan government to business sangatlah berkaitan satu sama lain karena akar masalah yang berkaitan dengan regulasi.

Berdasarkan apa yang dirumuskan dalam undang-undang ini, kesempatan penyelesaian terdapat pada Bab V tentang Penyelenggaraan, Pasal 7 ayat (2), huruf d. Pasal ini menjelaskan tentang pengembangan teknologi lalu lintas dan angkutan jalan meskipun tidak merinci pengembangan teknologi semacam apa. Selain itu di pasal yang sama huruf e, undang-undang ini menjelaskan peran Kepolisian untuk mendata keberadaan kendaraan bermotor. Lalu, penjelasan lebih lanjut dijabarkan pada Pasal 11 dan 12 undang-undang yang sama. Pemerintah dapat membuat peraturan baru yang mendukung Pasal 7 ayat (2) huruf d yang khusus untuk perusahaan transportasi berbasis jaringan online. Kementerian Komunikasi dan Informatika juga Kementerian Perhubungan memiliki peran besar dalam pembentukan regulasi yang baru. Selanjutnya kepolisian Republik Indonesia, melalui Korps Lalu Lintasnya, dapat menyesuaikan warna plat kendaraan bermotor tersebut sesuai dengan regulasi yang dibuat.

Selain dua kementerian tersebut, pemerintah daerah perlu membuat peraturan baru untuk tariff kendaraan angkutan umum model baru ini. Apabila sebelumnya transportasi online menang di pasar karena promo yang mereka tawarkan, maka 
berapakah tariff yang saat ini pantas diberlakukan memandang perbedaan penyediaan mobil, tipe mobil, pelatihan supir, perizinan, juga harga minyak dunia yang mempengaruhi harga BBM di Indonesia.

\section{Kesimpulan}

Persaingan yang dianggap tidak seimbang terkait konflik antara taksi konvensional dan taksi online bukan dikarenakan adanya indikasi monopoli ataupun persaingan usaha tidak sehat yang disebabkan oleh kedua atau salah satu moda transportasi tersebut, struktur biaya yang tidak sama antara keduanya membuat penetapan tarifpun tidak berangkat dari beban yang sama sehingga ada perbedaan yang sangat kontras dan signifikan antara keduanya. Tidak ada bagian dalam monopoli maupun persaingan usaha tidak sehat yang dilanggar oleh kedua belah pihak, persaingan yang tampak tidak sehat antara kedua kubu ini justru disebakan karena tidak adanya penegakan hukum dimana pemerintah belum siap merespons dinamika di ranah bisnis berbasis aplikasi online ini.

\section{Daftar Referensi}

Adisasmita, R. (2015). Analisis Kebutuhan Transportasi. Graha Ilmu.

Adisasmita, R., \& Adisasmita, S. (2011). Manajemen Transportasi Darat. Graha Ilmu.

Akyuwen, R. J., Labetubun, M. A. H., \& Pariela, M. V. G. (2021). Clausula Restrictions In Technology Transfer Patent License Agreements That Impact On Unfair Competition. Journal of Legal, Ethical and Regulatory Issues, 24(3), 1-9.

Badan perencanaan Pembangunan Nasional dan Badan Pusat Statistik. (2013). Proyeksi Penduduk Indonesia 2010-2035.

Beattie, V., Goodacre, A., \& Fearnley, S. (2003). And then there were four: A study of UK audit market concentration - causes, consequences and the scope for market adjustment. Journal of Financial Regulation and Compliance, 11(3), 250-265.

Ginting, E. R. (2001). Hukum Anti Monopoli Indonesia. Citra Aditya Bakti.

Hartono, S. (1999). Pembangunan Hukum Ekonomi Indonesia Dalam Rangka Mewujudkan Perilaku Bisnis Dan Persaingan Usaha Yang Sehat, Seminar: Membenahi Prilaku Pelaku Bisnis Melalui Undang-Undang No. 5 Tahun 1999 tentang Larangan Praktek Monopoli Dan Persaingan Usaha Tidak Sehat. Citra Aditya Bakti.

Hermansyah. (2008). Pokok-Pokok Hukum Persaingan Usaha Di Indonesia. Kencana Prenada Media Group.

Lubis, A. F., Anggraini, A. M. T., Toha, K., Kagramanto, L. B., Hawin, M., Sirait, N. N., Sukarmi, Maarif, S., \& Silalahi, J. U. (2009). Hukum Persaingan Usaha Antara Teks $\mathcal{E}$ Konteks. Deutsche Gesellschaft fur Technische Zusammenarbeit (GTZ) $\mathrm{GmbH}$.

Makarao, M. T., \& Suharsil. (2010). Hukum Larangan Praktik Monopoli dan Persaingan Usaha Tidak Sehat. Ghalia Indonesia. 
Marzuki, P. M. (2016). Penelitian Hukum,. Kencana. https:// doi.org/340.072

Nasution, M. (1993). Kaitan Pengembangan Teknologi dan Sumber Daya Manusia dengan Pengelolaan Ekonomi Makro, Seminar Nasional Pengembangan Teknologi dan Sumber Daya Manusia untuk Peningkatan Keunggulan Kompetitif dan Martabat Bangsa. Ugm Press.

Nugroho, S. A. (2012). Hukum Persaingan Usaha Di Indonesia Dalam Teori dan Praktik serta Penerapan Hukumnya. Kencana Prenada Media Group.

Panglaykim, J. (1983). Beberapa Aspek Ekonomi dan Bisnis Nasional dan Internasional. Ghalia Indonesia.

Safitri, M. (2015). Tinjauan Hukum Persaingan Usaha terhadap Konflik Taksi Konvensional dan Taksi Online. Jurnal Keadilan Progresif, 6(2), 138-148.

Stephen, M. (1989). Industrial Economics: Economics Analysis And Public Policy. Prentice Hall: New Jersey.

Warpani, S. P. (2002). Pengelolaan Lalu Lintas dan Angkatan Jalan. ITB Press. 